\title{
Distribution and types of windmills in Pomerania across the 19th century in the light of cartographic sources
}

\begin{abstract}
The aim of this text is to evaluate the distribution of windmills in Pomerania, an area which stretches from Gdańsk to Toruń, over the period of the nineteenth century. The basic research method was to analyse various maps from both the early nineteenth century and the late nineteenth century. The results made it possible to state that the total number windmills increased by a factor of three, and that this referred mainly to cereal mills. The number of vertical windmills with rotating caps increased at the beginning of the nineteenth century, but the number of drainage windmills remained unchanged. The very high demand for wind energy was a result of significant economic development within the Prussian partition in the second half of the nineteenth century. Cartographic sources allowed this phenomenon to be verified in the most complete way.

Keywords

Cartography $\bullet$ Pomerania $\bullet$ natural energy source $\bullet$ molinology $\bullet$ windmills - drainage mills
\end{abstract}

(c) University of Warsaw - Faculty of Geography and Regional Studies

\author{
Maciej Prarat \\ Faculty of Fine Arts, Nicolaus Copernicus \\ University in Toruń, Poland \\ e-mail: mprarat@umk.pl \\ Received: 5 November 2018 \\ Accepted: 4 January 2019
}

Introduction

Mills have been powered by the forces of nature for centuries; they constituted the main sources of energy for the production of food: mainly flour, beer, oils, mustard, sugar, etc. They were used in tanneries, the production of pigments and silk, cutting and polishing gems and stones, and cutting wood. Mills were also used in turneries, forges, waulk mills, paper mills, and finally as mine ventilation and extraction equipment (Notebaart 1972; Reynolds 1983; Hills 1996).

The purpose of this paper is to present the diversity in the number and types of windmills over the period of their most intensive use. Subsequently, an attempt will be made to determine the reasons for these changes and the provenance of the mill types.

The research covered the period from the beginning of the nineteenth century to the beginning of the twentieth century within the region of Pomerania, whose borders extend from Torun to Gdańsk. This area broadly coincides with the nineteenth century administrative division of the Province of West Prussia (when the area was under Prussian rule) and is divided ethnographically and historically into Chełmno Land, Tuchola Forests, Kashubia, Kociewie, Powiśle, and Żuławy (eds Czachowski \& Łopatyńska 2010). The thematic scope refers only to windmills, and considers all their types and functions.

The research method consisted of analysing maps from different time periods. Mills were carefully marked on historical maps as important landmarks, which was also related to their military significance. Tall structures among the fields served as observation and triangulation points for military artillerists (Mager 1990). Therefore, on some maps, windmills were marked in the legend as being 'visible from afar.'
Within the research, the location of each mill has been applied to the contemporary area, dividing the data chronologically into the very beginning of the nineteenth century, the second half of the nineteenth century, and the early twentieth century. Each mill was assigned a catalogue card, on which all their available information was included. For this purpose, additional inquiries were carried out in the state archives in Gdańsk, Toruń, and Bydgoszcz. From this data, material related to mill building permits was used.

The state of the research on the distribution and types of windmills in Pomerania is extremely modest. Apart from a few works by ethnographers (Łęga 1963; Święch 2001; Adamczewski 2005; Swięch 2005) and documentation for individual structures made for provincial offices for the protection of monuments (Domagała 1971), there is no comprehensive catalogue of windmills.

As for the Middle Ages, an analysis was made by Kubicki (2012) which was based on diverse written sources. The distribution and types of windmills, including their current state of preservation, was only presented for Chełmno Land (Prarat 2016) and the area of today's Kujawsko-Pomorskie voivodeship (Brykała et al. 2015); whereas issues related to watermills were demonstrated for the whole basin area of the Lower Vistula River (Podgórski 2004; Brykała 2018).

In conclusion, it should be stated that there is no comprehensive analysis of the number of windmills in this area in relation to different time frames, and cartographic sources were only used to a small extent to do so. Therefore, this text aims to fill this gap and is an attempt to link their increasing occurrence to the overall economic situation of the region. 


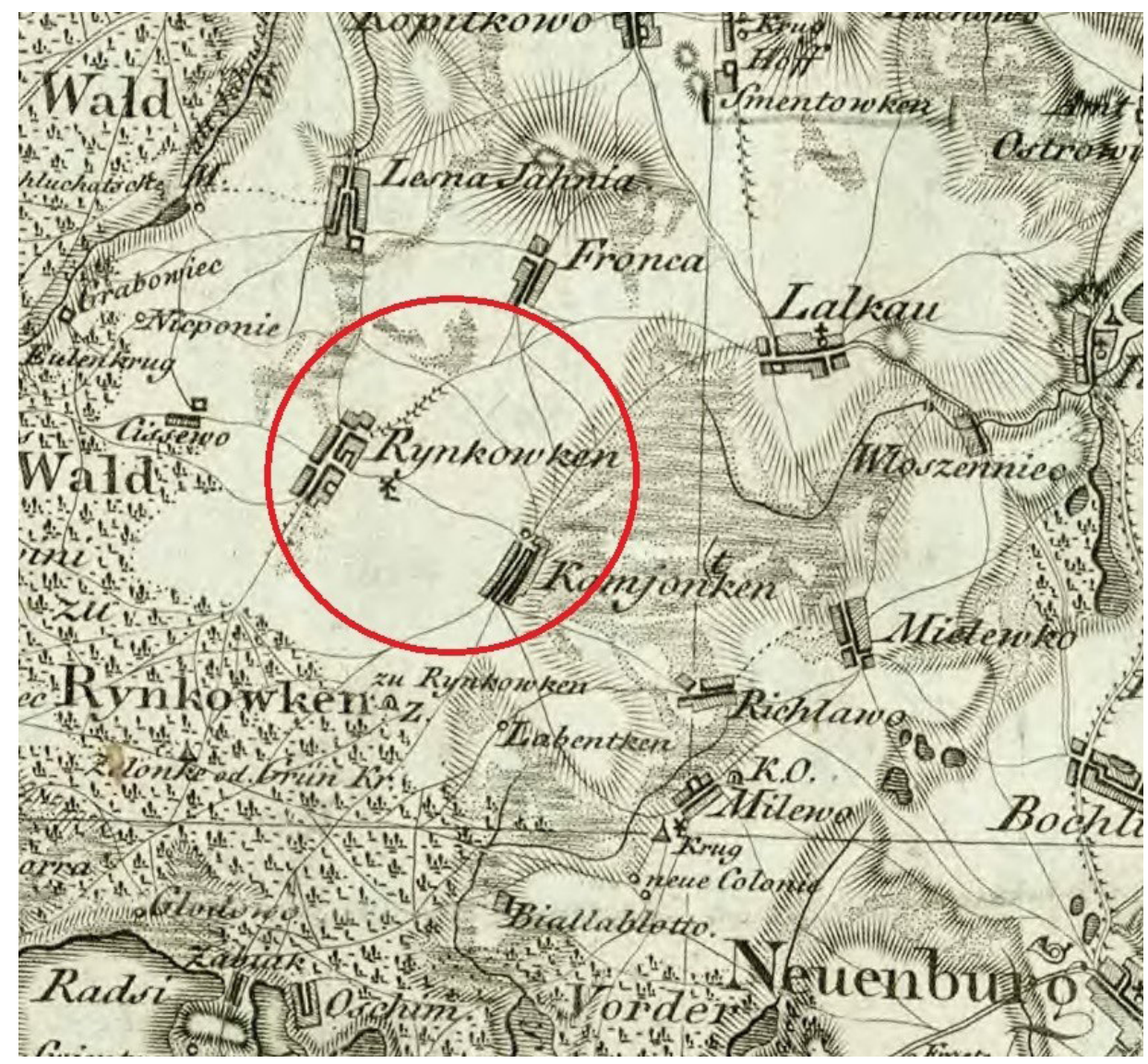

Figure 1. The graphic designation of a windmill from a fragment of Schrötter's map from the beginning of the nineteenth century. Source: Schrötter, L 1796-1802, Karte von Ostpreussen nebst Preussisch Litthauen und West-Preussen nebst dem Netzdistrict, Blatt XV, 1:150 000, Schropp u. Comp. Available from: <http://igrek.amzp.pl> [1 October 2018].

The text was created as part of a scholarship granted by the Ministry of Culture and National Heritage in 2018.

\section{Characteristics of the basic types of windmills}

Before discussing the results of the research, it is worth having a look at the basic types of windmills (Moog 2012; Moog 2018). The oldest type, which was popular in Europe from the second half of the twelfth century, is the post mill (Lucas 2011). Here a revolving building was placed on a vertical post. A variation on this is the hollow post mill, where a small rotating building sits on a tall foundation, often enclosed. In the Netherlands these were already popular in the fifteenth century (Stokhuyzen 1962). The former were essentially used to make flour, whereas the latter served mainly as drainage pumps.

The paltrock mill had a structure similar to the post mill. The difference, however, is that the building does not rotate on a main post, but on rollers located on the foundation. This construction was invented at the end of the sixteenth century especially for cutting wood, it was also in use in the Netherlands. Later, a system of several rollers was also used in grain windmills (Moog 2018). The last type is a windmill, also known from medieval times, was constructed so that only the upper part containing the wing shaft revolved. Depending on the design and the floor plan, these can be distinguished as tower mills, with a brick foundation based on a circular plan; and smock mills with a wooden structure of a six or eight-sided plan (Moog 2018). In this paper the two types are combined under vertical windmills with rotating cap.
Distribution and types of windmills based on cartographic sources

The area of Pomerania is geographically diverse. The plain of Żuławy Wiślane with its partial depression dominates the mouth of the Vistula River. A similar landscape can be seen in the lowlands of the lower Vistula valley. The largest forest complex in this area is the Tuchola Forests located on the left side of the Vistula River, while Kashubia is a hilly region (Kondracki 2002).

Windmills in this region were introduced and their construction encouraged by the Teutonic Order at the turn of the fourteenth century. By analysing their distribution, Kubicki (2012) was able to state that the largest number of the windmills was in Żuławy; which, of course, was related to the terrain, that is, a small number of rivers and large open spaces. As for some of the other locations, the fact that they were built faster and much cheaper resulted from a desire to supplement already functioning watermills to grind product. The function of these windmills was limited only to milling grain. If a plant was destroyed, usually the same location was used for rebuilding (Kubicki 2012).

While analysing cartographic sources, it ought to be stated that in terms of the nineteenth century there are two collections of maps which are most valuable. (Buczek 1935; Grabowski 2005; Konias 2010). The first is the Schrötter map from the beginning of the nineteenth century. In general circulation, it was available in 1:150,000 scale (Fig. 1). This was the basis for analysing the distribution of windmills. Subsequently, this information was supplemented by charts in 1:50,000 scale, which had been stored 


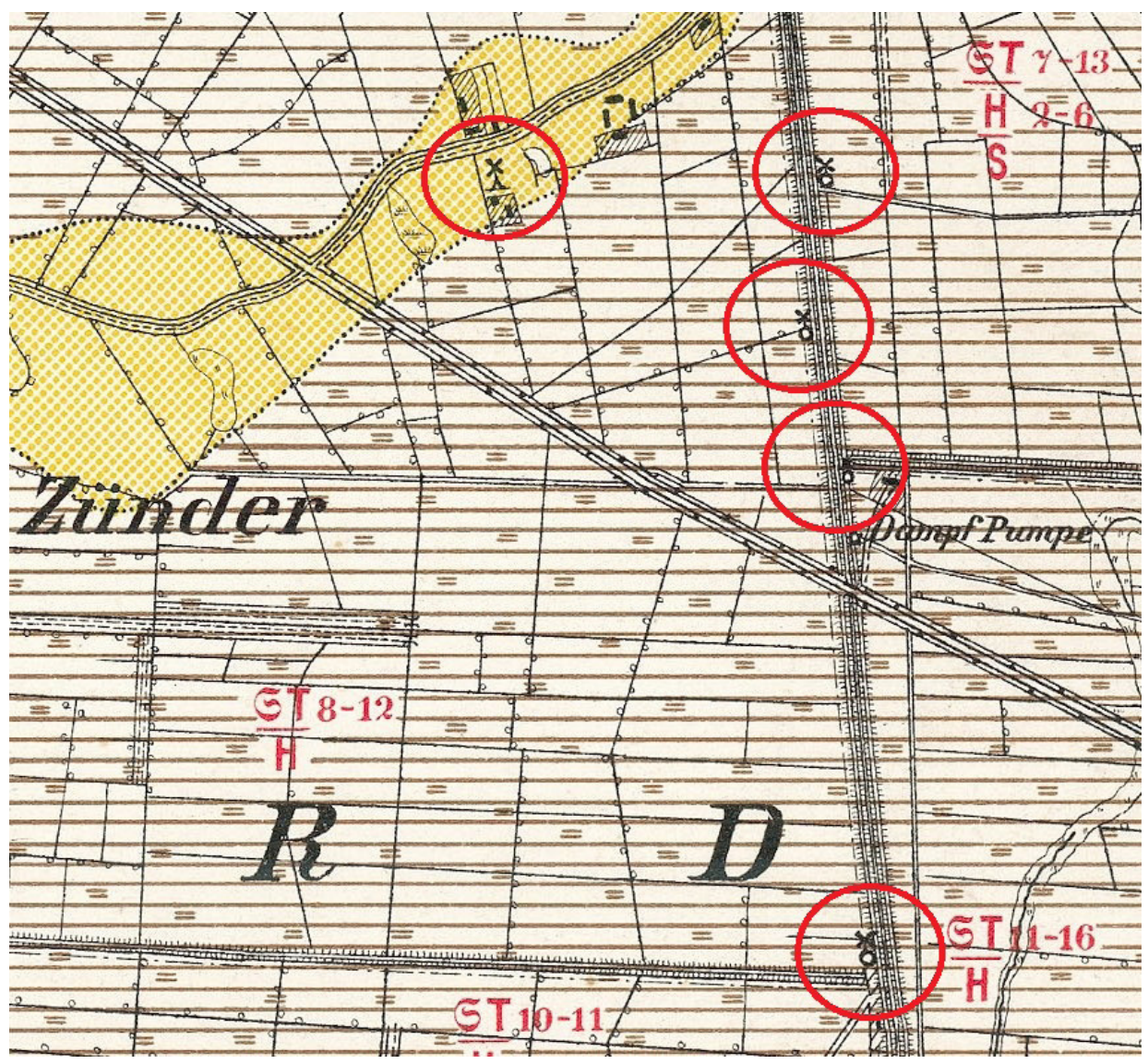

Figure 2. The graphic designation of a windmill from a fragment of ordnance map from the beginning of the twentieth century. Key: triangular base - post mill, wheel base - drainage mill.

Source: Messtischblätt, 1903, Kasemark nr 2779, 1:25 000, Available from: <www.mapy.eksploracja.pl> [1 October 2018].

in the Staatsbibliothek collection in Berlin. A number of windmills along with their geographical symbols are identical on both maps. In several cases, more accurate maps contain a summary of the mills' characteristics. For instance, the windmill in Rynkówek is precisely described as being a vertical windmill with a rotating cap and six pairs of stones (Schrötter 1796-108, Blatt 111.c). In some places, horse drainage mills were clearly marked as 'Ross Mühle zu ausschöpfen.'

In general, however, it is not possible to determine the types of mills on the basis of these maps. A more accurate division into post mills, drainage mills, and vertical windmills with rotating cap could be done by analysing some additional written and iconographic sources, as well as subsequent cartography.

The other source is the Prussian collection of ordnance maps from the second half of the nineteenth and the beginning of the twentieth centuries in 1:25,000 scale. In the legend, two windmill symbols are clearly highlighted - a post mill on a triangular base, and a vertical windmill with rotating cap on a wheel base.

The identification of drainage windmills is an important issue (Fig.2). These are usually marked as vertical windmills with a rotating cap with the base in the form of a wheel. Sometimes, the wheel looks like of the symbol for a watermill. In fact, the drainage mills used in Żuławy could be divided into hollow post mills and smock mills (Bertram 1925). Therefore, regardless of the type, windmills were generally assigned as being drainage windmills. Luckily, in most cases, a note - 'Entwasserung Mühle' - gives information about their function.
To verify the location of the mills, more precise drawings were also used. These maps, which were prepared in order to obtain building permits for new plants, turned out to be extremely helpful. The owner had to determine the structure's distance from roads and other buildings, which was connected with the provisions of construction law.

This was the case of a miller who wanted to build a post mill in the village of Dolna Grupa. It also happened, that at the site of an already existing windmill, a new one was built. A record of distances had to be kept here as well (Starostwo Powiatowe Świeckie, 1773-920). In 1838, another miller, Ferdinand Deppka, received a permit to build another post mill and a horse mill in Nowe nad Wisłą (Offentlicher Anzeiger, 1838).

A review of maps covering a period of over a hundred years also makes it possible to observe the changes in the landscape which are connected with windmills. At the beginning of the nineteenth century, a working windmill was marked as operating in Watkowice (Schrötter, L 1796-1802, Blatt XV). However, in 1895, there was only a windmill hill marked on the map, without the mill itself (Messtischblätt, 1895). This is still visible in the landscape today.

Is a full analysis of the number of mills possible on the basis of cartographic materials? It is definitely the most complete source, however, there are also gaps. These refer to the periods not taken into account by the Schrötter maps or the individual charts of the ordnance maps. This was the case, for instance, in the village of Mlewo. In 1849, a miller called Bolinger received 


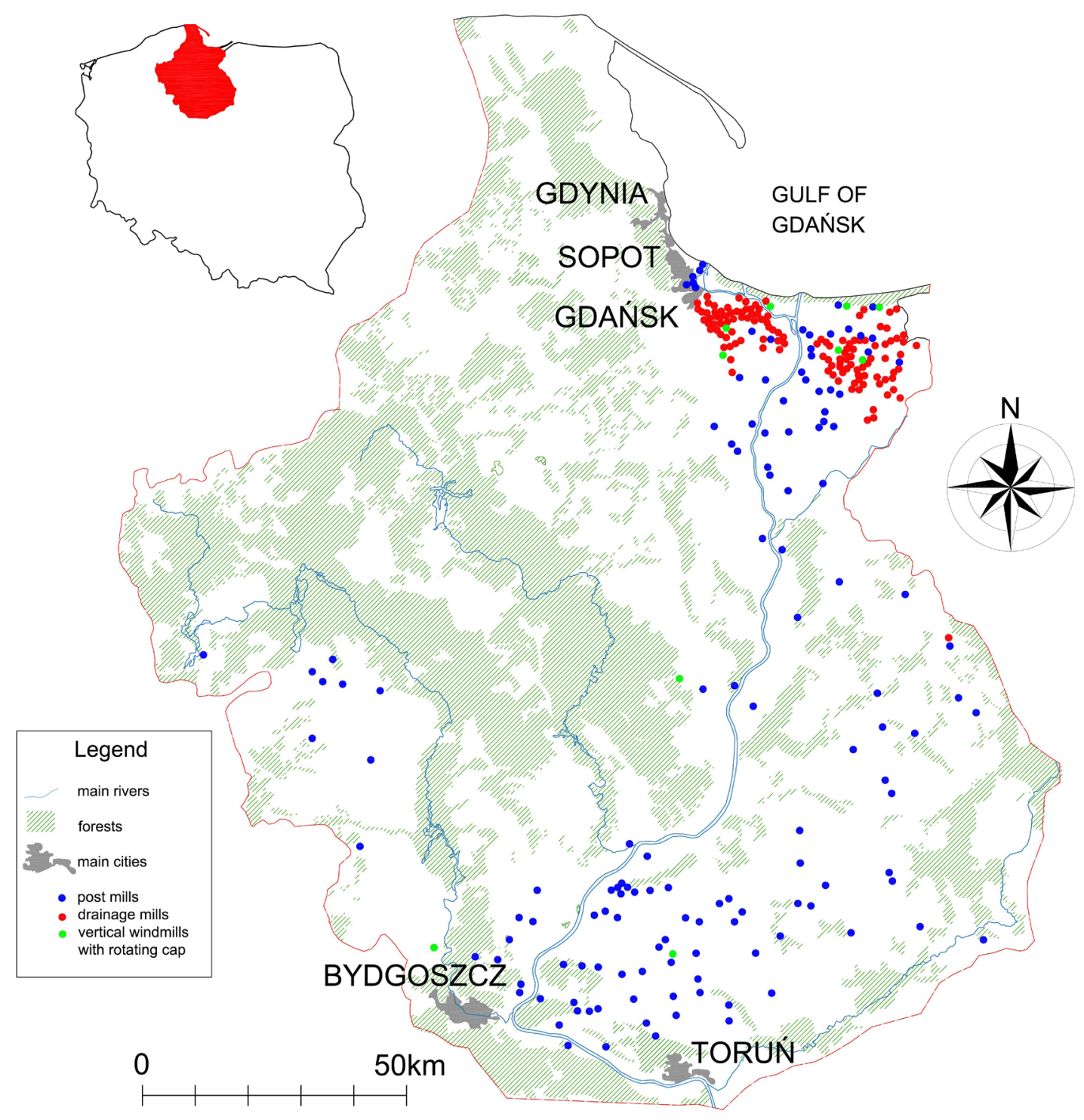

Figure 3. Distribution of windmills in Pomerania at the beginning of the nineteenth century. Source: Author's own work

permission to build a windmill. Nine years later, the building was destroyed and another miller, Thiel, applied to rebuild it (Starostwo Powiatowe Toruńskie, 1818-1920). Whether he obtained the permit and rebuilt the mill is not known - it has not been recorded in any cartographic source. A similar situation took place in the case of a windmill on Kozłowo farm (Starostwo Powiatowe w Kwidzynie, 17861945).

The analysis of the cartography together with some written sources allowed for a fairly accurate reconstruction of windmill distribution over the centuries. At the beginning of the nineteenth century, there were 264 windmills in the area (Fig. 3). At the turn of the twentieth century this number had increased to 736 (Fig. 4).

Looking in more detail, it can be stated that at the beginning of the nineteenth century there were 124 post mills and 123 drainage mills (hollow post mills and smock mills), which covers $47 \%$ of all windmills. At least 17 vertical windmills with a rotating cap were identified, which covers $6 \%$ of all windmills. We do not have any information about paltrock mills.
The distribution of the mills is interesting; in general, they are concentrated in two areas. The first area is Żuławy Wiślane, where mainly drainage windmills were recorded. Also half of all recorded vertical windmills with rotating cap were located in this region. The other area is Chełmno Land, where there were more than 60 post mills documented. Individual post mills could still be found near Chojnice, and between Kwidzyn and Grudziądz at the beginning of the nineteenth century. There were no windmills recorded in coastal areas or in Kashubia.

During the nineteenth and early twentieth centuries, the number of windmills increased to almost 736 . The number of post mills increased by more than $276 \%$, from 124 to 467 . They made up $63.4 \%$ of all the mills at that time. The number of vertical windmills with rotating cap increased by $588 \%$, from 17 to 117 , constituting $16 \%$ of all windmills. Paltrock mills from this period of time are also known, although they were not popular in this area. The number of drainage windmills changed slightly from 123 to 149 , which made up $20.2 \%$ of the total number. Comparing this 


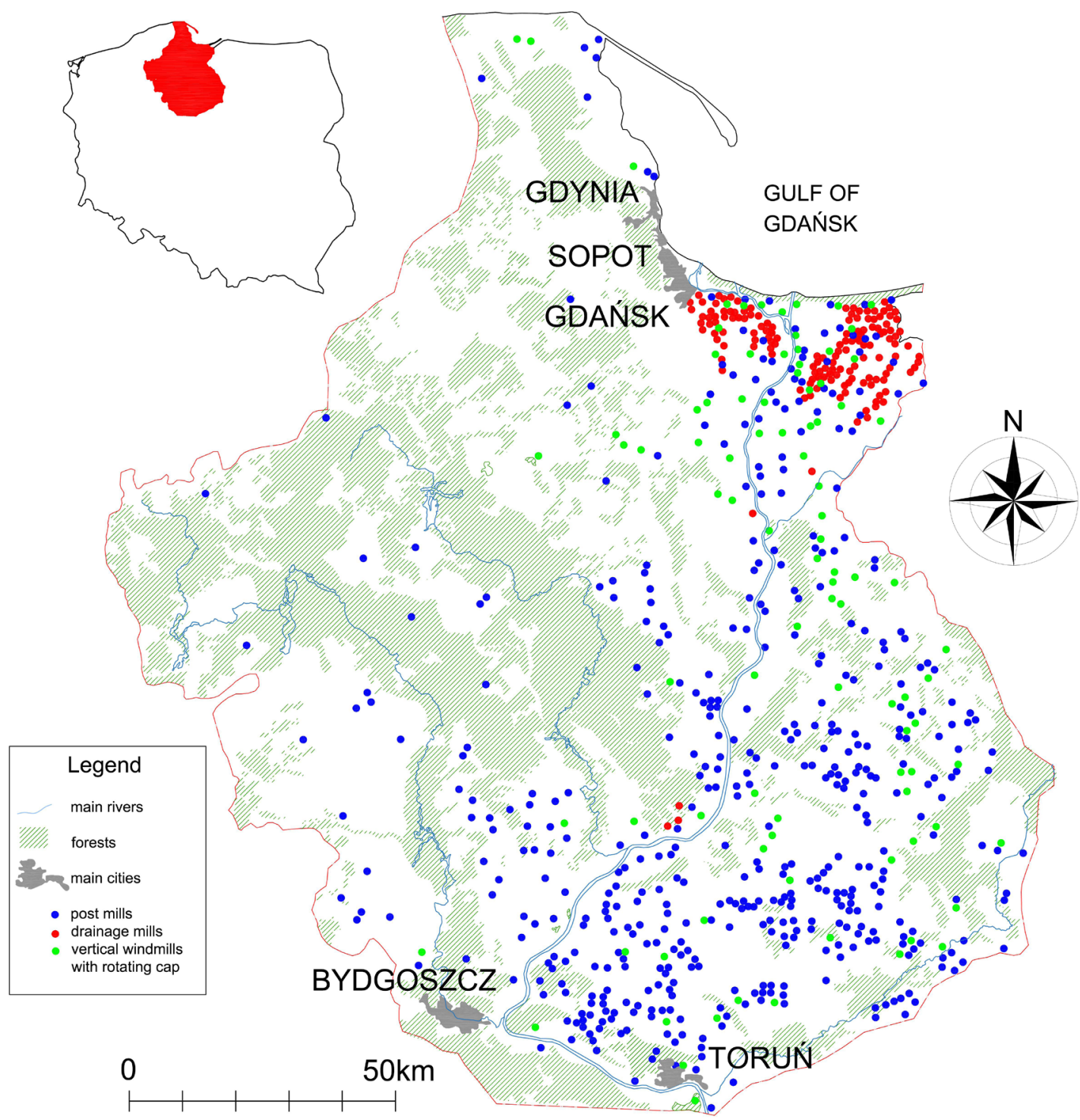

Figure 4. Distribution of windmills in Pomerania at the turn of the twentieth century. Source: Author's own work

number to their distribution, it should be noted that there were only slightly fewer in the same area of Zuławy. Individual wind drainage pumps were also found in the Lower Vistula Valley. An increase in the number of post mills is observable in Chełmno Land, and between Kwidzyn and Grudziądz; while the number increased slightly in Kashubia and Tuchola Forests. The vertical windmill with rotating cap still predominated in the north.

The figures show that the number of gristmills increased the most. The drainage system in the Żuławy region, formed at the beginning of the nineteenth century, underwent only a small expansion; and later it was quite rapidly replaced by engine driven pumps. The specific characteristics of their construction, applied particularly to hollow post mills, clearly defines the source of their origin. In the Netherlands, such solutions had been used since the Middle Ages, while in Żuławy they were built from the sixteenth to nineteenth century (Stokhuyzen 1962, Bertram 1925).

Throughout the nineteenth century, post mills were dominant, while in the second half of the century the vertical windmill with rotating cap gained popularity. They were definitely more expensive, but also more efficient. In Żuławy, smock mills were also equipped with several additional elements such as galleries, the foundation of the structure built on a high brick base with a passage, or, finally, placing windmills on buildings. These forms, unusual in other parts of Poland, also bring to mind the solutions used in the Netherlands (Stankiewicz 1956-1957). Tower mills occurred throughout the area, and their form was a common solution across Central Europe. When it comes to the post mills, it should be noted that mills in Żuławy were also characterized by a certain individuality (mainly in their form). However, all the known examples come mainly from the eighteenth century. As for the structures from Chełmno Land, built mainly in the nineteenth century, typical solutions were used here, and their designs were generally available in textbooks. We know this by analysing a number of archival files containing building permits, and it was often the case that identical, duplicated designs were used (Poviat Starosty of Toruń, 1818-1920). 
There is still a question about the areas where there were no windmills. These areas' heavy forestation made it impossible to use wind power. An analysis of watermill distribution provides the full answer to this question. They were mostly concentrated in the areas of Kashubia and Tuchola Forests, where they have been largely preserved until today. In general, this shows a fairly even distribution of industrial plants throughout Pomerania.

Why was the second half of the nineteenth century connected with such a dynamic demand for the use of wind energy? At the beginning of the nineteenth century, the coercion of grist was abolished. In the middle of the nineteenth century, the process of the enfranchisement of the peasants ended, which led to an increase in production (Stępiński 2000). In the second half of the nineteenth century, capitalist restructuring within agriculture stabilized: this was connected to the development of the railway and road networks. Politically, this was the time of the unification and the proclamation of the Second Reich (1871). Also, in the second half of the nineteenth century, dynamically developing industry ultimately led to a concentration of milling, which favoured large, mechanical mills with higher processing capacity (Włodarczyk 2000). However, these were built in larger urban centres. The first steam mill appeared in Gdańsk in 1836, and another a year later in Gniew (Baranowski 1977). Among other regions, grain was transported from Poznańskie voivodeship, the Kingdom of Poland, and the Russian Empire to the Pomorze region of Gdansk. A large proportion of flour was also exported to north German markets (Baranowski 1977). These factors led to a division into two main categories - large commercial and industrial plants; and smaller commercial ones, the number of which also increased significantly.

\section{Conclusion}

To summarize, between 264 to 736 windmills operated in Pomerania during the nineteenth century. The bulk of these were located in Żuławy and Chełmno Land. The occurrence of so many hollow post mills and smock mills leads to a search for analogies with the technical solutions used in the Netherlands, with which Gdańsk and Żuławy always maintained close contacts.
The quantitative change in windmills very clearly reflects the economic situation in West Prussia at this time. Significant economic and technological development resulted in a rapid growth in the number of windmills, although these were quickly replaced by large, efficient industrial mills, which worked regardless of the weather conditions.

Only in the 1920s did Prussian conservators call for the protection of the oldest and most valuable structures, which were an important element of the landscape and evidence of technological development. Unfortunately, only 17 windmills have survived to this day, the vast majority of which are in a state of ruin. None of them work, and most of them do not have any of their equipment preserved. Only two windmills have been protected by the Open air Museum in Kashubia. A mere two post mills have survived in the Chełmno area, only one of which has been renovated. In Żuławy, where windmills were the most characteristic element of the lowlands, none is properly protected

An unresolved issue remains concerning the tradition of situating windmills in the same places. Is it possible to determine the location of windmills from the Middle Ages on the basis of the nineteenth century cartography? This question can only be answered with the help of archaeological research.

In conclusion, the cartographic sources provide the most complete picture of mill development during the nineteenth century. The research conducted here has also proved that the greatest diversity of the windmill types and functions in Poland occurs precisely in Pomerania. Discussion regarding their construction or equipment is possible only on the grounds of written sources and an analysis of the structure of the monuments themselves

\section{References}

Adamczewski, J 2005, Młynarstwo magiczne [Magic milling], Polskie Towarzystwo Ludoznawcze, Wrocław.

Baranowski, B 1977, Polskie młynarstwo [Polish milling], Zakład Narodowy imienia Ossolińskich, Wrocław-WarszawaKraków-Gdańsk.

Bertram, H 1925, Neuere Grundsätze für Schöpfwerksbauten [The latest rules of drainage machines construction], Paul Parey Verlag für Landwirtschaft, Gartenbau und Forstwesen, Berlin.

Brykała, D 2018, Reconstruction of disposable water resources stored in mill ponds in Poland in the late $18^{\text {th }}$ century in Gestione dell'acqua in Europa (XII-XVIII Secc.)/Water management in Europe (12 $12^{\text {th }}-18^{\text {th }}$ Centuries), University Press, Firenze, pp. 337-352.

Brykała, D, Podgórski, Z, Sarnowski, Ł, Lamparski, P \&Kordowski, J 2015, Wykorzystanie energii wiatru $i$ wody w okresie ostatnich 200 lat na obszarze województwa kujawskopomorskiego [Using wind and water power in last 200 years in the area of Kuyavian-Pomeranian voivodship] in Prace Komisji Krajobrazu Kulturowego [Works of the Cultural Landscape Committee], No 29, pp. 9-22.

Buczek, K 1935, Prace kartografów pruskich w Polsce za czasów króla Stanisława Augusta, na tle współczesnej kartografji polskiej (z dodatkami i 9 tablicami) [Works of Prussian cartographers in king Stanisław August's times in the light of Polish contemporary cartography] in Prace Komisji Atlasu Historycznego Polski [Works of the Committee of Historical Atlas of Poland], 3, Kraków, pp. 115-322.

Czachowski H \& Łopatyńska H (eds) 2010, Tajemnice codzienności. Kultura ludowa i jej pogranicza od Kujaw do Bałtyku (1850-1950) [Secrets of every-day reality Folk culture and its borderlands from Kuyavia to the Baltic Sea,18501950], Muzeum Etnograficzne im. Marii ZnamierowskiejPrüfferowej w Toruniu, Toruń.

Domagała, T 1971, Wiatraki w województwie gdańskim [Windmills in Gdańsk voivodship], Gdańsk, Available from: Oddział Gdański Narodowego Instytutu Dziedzictwa [National Heritage Board of Poland, branch of Gdańsk].

Grabowski, P 2005, Szczegółowa topografia Prus Wschodnich i Zachodnich na mapie Fryderyka Leopolda Schröttera (17961802) [Detailed Topography of East and West Prussia on the map of Fryderyk Leopold Schrötter] in Komunikaty MazurskoWarmińskie [Mazursko-Warmińskie Notes], nr 4, pp. 555-559.

Hills, RL 1996, Power from wind. A history of windmill technology, University Press, Cambridge.

Kondracki, J 2002, Geografia regionalna Polski [Regional Geography of Poland], Wydawnictwo Naukowe PWN, Warszawa. 
Konias, A 2010, Kartografia topograficzna państwa i zaboru pruskiego od II połowy XVIII wieku do połowy XX wieku [Topographic cartography of the Prussian state and partition from the second half of the 18th century to mid-20th century], Wydawnictwo Naukowe Akademii Pomorskiej, Słupsk.

Kubicki, R 2012, Młynarstwo w państwie zakonu krzyżackiego w Prusach w XIII-XV wieku (do 1454 r.) [Milling in the state of Teutonic Knights in Prussia from $13^{\text {th }}$ to $15^{\text {th }}$ century (till 1454)], Wydawnictwo Uniwersytetu Gdańskiego, Gdańsk.

Lucas, A 2011, Wind, water, work. Ancient and Medieval Milling Technology, Brill, Leiden-Boston.

Łęga, W 1963, Ziemia chełmińska [Chełmno Land], Polskie Towarzystwo Ludoznawcze, Wrocław.

Mager, J 1990, Mühlenflügel und Wasserrad [Millwing and Waterwhee/], VEB Fachbuchverlag, Leipzig.

Messtischblätt, 1903, Kasemark nr 2779, 1:25 000, Available from: <www.mapy.eksploracja.pl> [1 October 2018].

Moog, B 2012, Einführung in die Mühlenkunde. Grundlage, Technik, Geschichte und Kultur der traditionellen Mühlen [Introduction to Molinology. History, Technique and Culture of Traditional Mills], Vereinigung Schweizer Mühlenfreunde, Binningen.

Moog, B 2018, Introduction to Molinology. History, Technique, and Culture of Traditional Mills, Digital Archive of The International Molinological Society (TIMS), Binningen.

Notebaart, JC 1972, Wndmühlen. Der Stand der Forschung über das Vorkommen und den Ursprung [Windmills. The state of research of localisation and origins], Mouton Verlag, Den Haag-Paris.

Offentlicher Anzeiger [Public Informer], 1838, Beilage des Amtsblatts nr 21 [An Attachment to the Official Journal]. Der Königlichen Preuß. Regierung, Marienwerder [Royal Prussian Region in Kwidzyn], den 25ten Mai.

Podgórski, Z 2004, Wpływ budowy i funkcjonowania młynów wodnych na rzeźbę terenu i wody powierzchniowe pojezierza chełmińskiego i przyległych części dolin Wisły i Drwęcy [Influence of constructing and operating of the watermills on the landform and surface waters in lake Chełmno region and adjacent parts of the Vistula and Drwęca valleys], Wydawnictwo UMK, Torun.

Prarat, M 2016, Sketches from the history of milling in Chełmno Land (in the north of Poland) in International Molinology, No 93, pp. 21-29.

Reynolds, TS 1983, Stronger than a Hundred Men, The John Hopkins University Press, Baltimore-London.

Schrötter, L 1796-1802, Karte von Ostpreussen nebst Preussisch Litthauen und West-Preussen nebst dem Netzdistrict [Map of East Prussia together with Prussian Lithuania, West Prussia and Nadnotecki District], Blatt [Sheet] 111.c, 1:50 000, S Schropp u. Comp. Available from: Staatsbibliothek zu Berlin, sign. N1020.

Schrötter, L 1796-1802, Karte von Ostpreussen nebst Preussisch Litthauen und West-Preussen nebst dem Netzdistrict [Map of East Prussia together with Prussian Lithuania, West Prussia and Nadnotecki District], Blatt [Sheet] XV, 1:150 000, Schropp u. Comp. Available from: <http://igrek.amzp. pl> [1 October 2018].

Stankiewicz, J 1956-1957, Zabytki budownictwa i architektury na Żuławach [Engineering and Architectural Monuments in Żuławy], Rocznik Gdański [Yearbook Gdański], vol. XV-XVI, Gdańsk, p. 526-527.

Starostwo Powiatowe Świeckie 1773-1920 [District Office in Świecie 1773-1920], Available from: Archiwum Państwowe w Bydgoszczy [National Archive in Bydgoszcz], sign. 203.
Starostwo Powiatowe Toruńskie 1818-1920 [District Office in Toruń 1818-1920], Available from: Archiwum Państwowe w Toruniu [National Archive in Toruń], sign. 651.

Starostwo Powiatowe w Kwidzynie 1786-1945 [District Office in Kwidzyn 1786-1945], Fabrikanlage [Factory Investment] 1881-1895, Available from: Archiwum Państwowe w Gdańsku [National Archive in Gdańsk], sign. 85.

Stępiński, W 2000, Wieś pomorska w drugiej połowie XIX i na początku XX wieku [Pomeranian village in the second half of the 19th century and the beginning of the 20th century] in Stosunki społeczno-gospodarcze [Social and economic relations] in Historia Pomorza [History of Pomerania], vol. IV (1850-1918), part 1, Ustrój, gospodarka, społeczeństwo [Political system, economy, society], ed S. Salmonowicz, Wydawnictwo Towarzystwa Naukowego Toruńskiego, Toruń, pp. 137-149.

Stokhuyzen, F 1962, The Dutch Windmill, C.A.J. van Dishoeck.

Święch, J 2001, Wiatraki. Młynarstwo wietrzne na Kujawach [Windmills. Wind milling in Kujawy], Oficyna Wydawnicza Włocławskiego Towarzystwa Naukowego, Włocławek.

Święch, J 2005, Tajemniczy świat wiatraków [Mysterious world of windmills], Polskie Towarzystwo Ludoznawcze, Łódź.

Włodarczyk, E 2000, Rozwój gospodarczy miast pomorskich w latach 1850-1894 [Economic development of Pomeranian towns in the years 1850-1894] in Historia Pomorza [History of Pomeranian], vol. IV (1850-1918), part 1, Ustrój, gospodarka, społeczeństwo [Political system, economy, society], ed. S. Salmonowicz, Wydawnictwo Towarzystwa Naukowego Toruńskiego, Toruń, pp. 136-394. 